\title{
GLEIVINIŲ MELANOMOS IMUNOTERAPIJA: KLINIKINIS ATVEJIS IR LITERATŪROS APŽVALGA
}

\author{
Rugilè Pikturnienė, Jolanta Česienė, Henrieta Janušonytė \\ Klaipédos universitetiné ligoniné
}

Raktažodžiai: gleivinių melanoma, imunoterapija, nivolumab, ipilimumab.

\section{Santrauka}

Gleiviniu melanoma yra labai reta melanomos forma, kuri pasireiškia nespecifiniais simptomais, tokiais kaip skausmas ar kraujavimas iš židinių, dažniausiai randamų galvos ir kaklo regione, anorektaliniame regione ir lytinių organų gleivinèje. Gleivinių melanomos diagnostika neretai būna uždelsta, todèl liga diagnozuojama vèlyvesnèse stadijose, o ir jos eiga yra agresyvesnè. Straipsnyje pristatomas sėkmingas metastatinès melanomos burnos gleivinès gydymo atvejis ir pateikiama literatūros apžvalga apie gleivinių melanomos gydymo imunoterapijos metodu rezultatus.

\section{Ivadas}

Melanoma - heterogeninè, sudètinga, pasižyminti ịvairiomis mutacijomis ir formomis, greitai metastazuojanti piktybinè liga [1].

Burnos gleivinès melanoma yra itin reta melanomos forma, kuri atsiranda iš nekontroliuojamų melanocitų augimo, kurie randami gleivinès ląstelių bazaliniame sluoksnyje. Šis melanomos tipas sudaro apie $0,2-1$ proc. visų me- lanomos diagnozių [2]. Norint palyginti gleivinių ir odos melanomą, stebima labai agresyvi ligos eiga, dažni recidyvai ir tolimosios metastazès. 5 metų išgyvenamumas be ligos atsinaujinimo siekia nuo 0 iki 20 procentų [3]. Apie 50 proc. visų gleivinès melanomų randamos galvos ir kaklo regione, likusią dali sudaro anorektalinès ar lytinių organų gleivinių melanomos. Neišplitusios, lokalizuotos gleivinių melanomos gydymas yra chirurginis, atliekant plačią eksciziją, tačiau neretai tai neịmanoma dèl anatominès padèties, o ir atlikus tinkamą darinio rezekciją, recidyvo dažnis labai didelis [4]. Melanomai būdingos genetinès mutacijos. Odos melanomos atveju labai dažna BRAF mutacija (apie $50 \%$ ), gleiviniu melanomos atveju diagnozuojama kur kas rečiau (apie $10 \%$ ) [5], tačiau c-kit geno pakitimai dažnesni gleivinių (iki $25 \%$ ) nei odos melanomos atvejais (5-10\%) [6]. NRAS mutacijos randamos 25 proc. gleivinès melanomos atvejų [7]. Ilgus dešimtmečius iki imunoterapijos atsiradimo metastatinès melanomos gydymas buvo labai ribotas, o pacientų išgyvenamumas itin trumpas. Metastatinès melanomos gydymui buvo patvirtinti trys imunoterapiniai preparatai: nivolumab, pembrolizumab, ipilimumab, kurie pakeite ne tik sergančiujju išgyvenamumą, bet ir jų gyvenimo kokybę.

Tikslas - pristatyti sèkmingą metastatinès melanomos burnos gleivinès gydymo atveji.
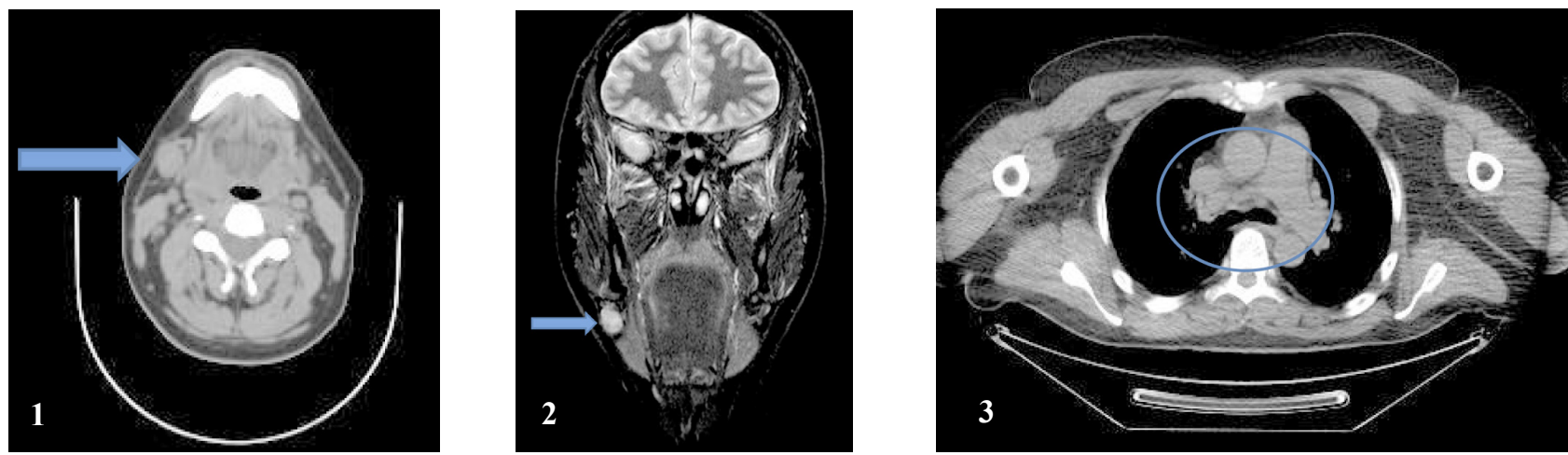

1,2,3 pav. Kaklo MRT, krūtinès KT ligos išplitimas 


\section{Klinikinis atvejis}

41 metų vyras pasiskundẻ dariniu dešiniojo skruosto gleivinejje. Konsultuotas odontologo, nukreiptas veido ir žandikaulių chirurgo konsultacijai, kuris nutare darinị išoperuoti. Histologinio tyrimo metu buvo diagnozuota išopejusi melanoma. BRAF geno mutacijos nerasta. Pacientui paskirtas nuodugnesnis ištyrimas: vidaus organų echoskopijoje pakitimų nestebèta. Kaklo MRT (1,2,3 pav.) dešiniojo skruosto srityje parodè 3,2 x 1,9 cm dydžio, kaupiantį kontrastinę medžiagą darinị, nusitęsiantị ị žandikaulio alveolinị kaulą, su metastazèmis kaklo limfmazgiuose. PET KT parodè dešiniojo skruosto lokaliai išplitusį, metaboliškai aktyvų navikinị procesą su dauginemis metastazèmis tarpuplautyje, prie diafragmos kojyčių esančiuose limfmazgiuose ir kaklo limfmazgiuose. Tuo metu dar nesant galimybès pacientą gydyti kitaip, pradedama chemoterapija karboplatin su paklitakseli. Pacientas gavo 6 gydymo kursus, o MRT buvo stebimas teigiamas efektas. Po 3 mènesių stebimas ligos progresas $(4,5,6$ pav.) tarpuplaučio paratrachèjiniuose limfmazgiuose, ties bifurkacija, viršraktikaulinèje zonoje ir metastazė stuburo krūtininès dalies antrajame slankstelyje. Pacientui pradedamas gydymas ipilimumab su nivolumab. Po 2 kursų stebimas nežymus navikinių limfmazgių augimas, tačiau vertinamas kaip pseudoprogresija. Vèliau gydymas tęsiamas tik nivolumabu. Atliekant kontrolinius tyrimus KT, MRT ir PET KT po 6 mènesių stebetas visiškas ligos išnykimas. Ligos atsinaujinimo nepastebèta jau beveik 6 metus. Pacientas jaučiasi gerai, darbingas, neturi jokių ligos simptomų.

\section{Diskusija}

Pristateme retą ir sėkmingą burnos gleivinès metastatinès melanomos atvejic. Tai agresyvus, greitai po gydymo progresavęs navikas, kuris ị imunoterapiją sureagavo ne iš karto, tačiau galutinis atsakas buvo ilgalaikis: tiek pirminis navikas, tiek metastatiniai židiniai visiškai išnyko.

Dèl mažo gleivinès melanoma dažnio, šių pacientų gydymo galimybès yra ribotos. Nors sisteminès terapijos yra kur kas mažiau efektyvios šios formos atveju, palyginus su odos melanoma, šiems pacientams skiriami tie patys gydymo režimai. Neretai literatūroje aprašomi pavieniai klinikiniai atvejai, o klinikių tyrimų duomenys itin riboti.

Viename klinikinių tyrimų stebèta, kad ne odos melanomos atveju, esant pirminiam navikui gleivinèse, šių pacientu atsakas i gydymą chemoterapija dakarbazin preparatu yra prastas [8]. Skelbiami vienos klinikos klinikiniai tyrimai, iš kurių viename gleivinių melanoma buvo gydoma įvairių medikamentų kombinacijomis: cisplatin, vinblastin, dakarbazin, interleukin -2 , interferon alfa, o atsako dažnis stebètas tarp 36 ir 47 proc., tačiau šiuose tyrimuose dalyvavo labai mažai $(11-18)$ tiriamujų, o ir atsako trukmè buvo trumpa $[9,10]$. Nuo tada, kai imunoterapija tapo pagrindiniu metastatinès melanomos gydymo metodu, atsirado ir retrospektyviniu duomenų iš gleivinès melanomos pacientų grupių, tačiau dèl mažo pacientų skaičiaus duomenis neretai sunku analizuoti. Didžioji dalis duomenų apie šią ligą ir jos gydymą skelbiama pacientų vaistų prieinamumo programose [11, 12]. Atsižvelgiant ị pranešimus, ligos atsako dažnis, naudojant gydymą ipilimumab, yra panašus kaip ir bendroje metastatinès melanomos populiacijoje [13]. Vienoje retrospektyvinèje analizejje, pacientų, gydytų ipilimumab, bendras ligos atsako dažnis siekè 6,7 proc., o ligos kontrolę pasiekè 23,3 proc. pacientų [14]. Panašūs rezultatai buvo gauti ir viename didžiausių, italų koordinuotų klinikinių tyrimų, kuriame buvo įtrauktas 71 pacientas, sergantis metastatine gleivinès melanoma. Tyrimas patvirtino ipilimumab veiksmingumą bendram išgyvenamumui ir ligos naštos sumažinimui [15]. II fazès DeCOG klinikiniame tyrime buvo ịtraukti skirtingomis metastatinès melanomos formomis sergantys pacientai, kuriems anksčiau taikyti skirtingi gydymo būdai, klinikinio tyrimo metu gydyti ipilimumab. Iš visų pacientų, 7 sirgo išplitusia gleivinių melanoma. 1 metų bendro išgyvenamumo dažnis šioje grupejje buvo 14 proc., tačiau visi pacientai mire praejjus 24 mėnesiams nuo gydymo pradžios. Iš šių pacientų vienas buvo pasiekęs dalinį ligos atsaką, o $\mathrm{du}$ - stabilią ligos eigą [16]. Šiuo atveju, taip pat kaip ir
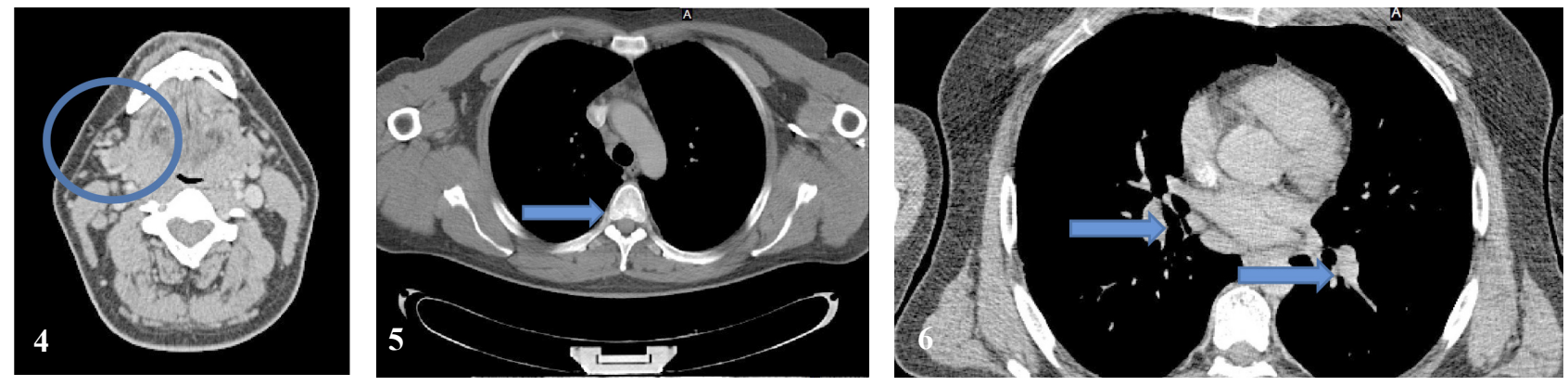

$\mathbf{4 , 5 , 6}$ pav. KT stebimas ligos progresas 
mūsų pristatytuoju klinikiniu atveju, imunoterapijai būdingas uždelstas veikimas arba pseudoprogresija, kuris kai kuriais atvejais veda ir ị visišką ligos išnykimą [17].

Šiuo metu klinikiniuose tyrimuose įrodyta neabejotina nauda derinant imunoterapijos preparatus. Viename III fazès klinikiniame tyrime, kuriame buvo įtraukti 86 išplitusia gleivinès melanoma sergantys pacientai, buvo lyginama gydymo nivolumab ir ipilimumab su nivolumab deriniu nauda. Objektyvus atsako dažnis siekè 23,3 proc. nivolumab grupeje ir 37,1 proc. vaistų derinio grupeje. Vidutinis išgyvenamumas be ligos progreso taip pat buvo ilgesnis vaisto derinio grupejje (5,9 mènesio ir 3 mènesiai) [18]. Šie duomenys leidžia teigti, kad terapija vaistų deriniu yra efektyvesnè.

\section{Išvados}

Gleivinių melanoma yra reta ir labai agresyvi melanomos forma. Daugelyje klinikinių atvejų aprašomos itin blogos šios ligos prognozès. Inovatyvūs imunoterapijos gydymo metodai kai kuriems pacientams gali suteikti ilgalaikị išgyvenamumą ir visišką ligos išnykimą, kaip ir aprašytuoju atveju.

\section{Literatūra}

1. Davis LE, Shalin SC, Tackett AJ. Current state of melanoma diagnosis and treatment. Cancer Biology and Therapy 2019; 20:1366-79

https://doi.org/10.1080/15384047.2019.1640032

2. Mihajlovic M, Vlajkovic S, Jovanovic P, Stefanovic V. Primary mucosal melanomas: a comprehensive review. International Journal of Clinical and Experimental Pathology 2012;5(8):73953.

3. Postow MA, Hamid O, Carvajal RD. Mucosal Melanoma: pathogenesis, clinical behavior, and management. Current Oncology Reports 2012;14:441-8.

https://doi.org/10.1007/s11912-012-0244-x

4. Patel SG, Prasad ML, Escrig M, Singh B, Shaha AR, Kraus DH, Boyle JO, Huvos AG, Busam K, Shah JP. Primary mucosal malignant melanoma of the head and neck. Head Neck 2002;24:247-57.

https://doi.org/10.1002/hed.10019

5. Curtin JA, Fridlyand J, Kageshita T, Patel HN, Busam KJ, Kutzner H, Cho KH, Aiba S, Brocker EB, LeBoit PE, Pinkel D, Bastian BC. Distinct sets of genetic alterations in melanoma. The New England Journal of Medicine 2005;353:2135-47. https://doi.org/10.1056/NEJMoa050092

6. Beadling C, Jacobson-Dunlop E, Hodi FS, Le C, Warrick A, Patterson J, Town A, Harlow A, Cruz F, Azar S, Rubin BP, Muller S, West R, et al. KIT gene mutations and copy number in melanoma subtypes. Clinical Cancer Research 2008;14:6821-8. https://doi.org/10.1158/1078-0432.CCR-08-0575

7. Si L, Wang X, Guo J. Genotyping of mucosal melanoma. Chinese Clinical Oncology 2014;3(3):34.
8. Yi JH, Yi SY, Lee HR, Lee SI, Lim DH, Kim JH, Park KW, Lee J. Dacarbazine-based chemotherapy as first-line treatment in noncutaneous metastatic melanoma: multicenter, retrospective analysis in Asia. Melanoma Research 2011;21:223-7.

https://doi.org/10.1097/CMR.0b013e3283457743

9. Bartell HL, Bedikian AY, Papadopoulos NE, Dett TK, Ballo MT, Myers JN, Hwu P, Kim KB. Biochemotherapy in patients with advanced head and neck mucosal melanoma. Head Neck 2008;30:1592-8.

https://doi.org/10.1002/hed.20910

10. Harting MS, Kim KB. Biochemotherapy in patients with advanced vulvovaginal mucosal melanoma. Melanoma Research 2004;14(6):517-20.

https://doi.org/10.1097/00008390-200412000-00012

11. Alexander M, Mellor JD, McArthur G, Kee D. Ipilimumab in pretreated patients with unresectable or metastatic cutaneous, uveal and mucosal melanoma. Med J Aust 2014;201:49-53. https://doi.org/10.5694/mja13.10448

12. Ascierto PA, Simeone E, Sileni VC, Pigozzo J, Maio M, Altomonte M, Del Vecchio M, Di Guardo L, Marchetti P, Ridolfi R, Cognetti F, Testori A, Bernengo MG, et al. Clinical experience with ipilimumab $3 \mathrm{mg} / \mathrm{kg}$ : real-world efficacy and safety data from an expanded access programme cohort. J Transl Med 2014; $12: 116$.

https://doi.org/10.1186/1479-5876-12-116

13. Hersh EM, O'Day SJ, Powderly J, Khan KD, Pavlick AC, Cranmer LD, Samlowski WE, Nichol GM, Yellin MJ, Weber JS. A phase II multicenter study of ipilimumab with or without dacarbazine in chemotherapy-naive patients with advanced melanoma. Investigational New Drugs 2011;29:489-98.

https://doi.org/10.1007/s10637-009-9376-8

14. Postow MA, Luke JJ, Bluth DJ, Ramaiya N, Panageas KS, Lawrence DP, Ibrahim N, Flaherty KT, Sullivan RJ, Ott PA, Callahan DK, Harding JJ, D'Angelo SP, et al. Ipilimumab for patients with advanced mucosal melanoma. Oncologist 2013;18:726-32.

https://doi.org/10.1634/theoncologist.2012-0464

15. Hoos A, Ibrahim R, Korman A, Abdallah K, Berman D, Shahabi V, Chin K, Canetta R, Humphrey R. Development of ipilimumab: contribution to a new paradigm for cancer immunotherapy. Semin Oncol 2010;37:533-46.

https://doi.org/10.1053/j.seminoncol.2010.09.015

16. Zimmer L, Eigentler TK, Kiecker F, Simon J, Utikal J, Mohr P, Berking C, Kampgen E, Dippel E, Stadler R, Hauschild A, Fluck M, Terheyden P, et al. Open-label, multicenter, single-arm phase II DeCOG-study of ipilimumab in pretreated patients with different subtypes of metastatic melanoma. Journal of Translational Medicine 2015;13.

https://doi.org/10.1186/s12967-015-0716-5

17. Wilgenhof S, Du Four S, Everaert H, Neyns B. Patterns of response in patients with pretreated metastatic melanoma who received ipilimumab $3 \mathrm{mg} / \mathrm{kg}$ in a European expanded access 
program: five illustrative case reports. Cancer Investigation 2012;30:712-20.

https://doi.org/10.3109/07357907.2012.727934

18. D'Angelo SP, Larkin J, Sosman JA, Lebbe C, Brady B, Neyns B, Schmidt H, Hassel JC, Hodi FS, Lorigan P, Savage KJ, Miller WH, Mohr P, et al. Efficacy and safety of nivolumab alone or in combination with ipilimumab in patients with mucosal melanoma: a pooled analysis. Journal of Clinical Oncology 2017;35:226-235.

https://doi.org/10.1200/JCO.2016.67.9258

\section{IMUNOTHERAPY FOR MUCOSAL MELANOMA: \\ CASE REPORT AND A LITERATURE REVIEW}

R. Pikturnienė, J. Česienė, H. Janušonytė

Keywords: mucosal melanoma, imunotherapy, nivolumab, ipilimumab.
Summary

Mucosal melanoma is an extremely rare form of melanoma presenting variably as sores or unexplained bleeding located mainly in the head and neck region, anorectal region or female genital tract. Mucosal melanoma is usually diagnosed at an advanced stage and is characterized by an aggressive behavior. Here I will present a case of successful treatment of metastatic oral mucosal melanoma.

Correspondence to: rugile.pikturniene@gmail.com

Gauta 2020-11-27 